\title{
DIVERSIFIKASI INTERNASIONAL DAN KINERJA PERUSAHAAN MANUFAKTUR DI INDONESIA DENGAN EFISIENSI SEBAGAI VARIABEL MODERASI
}

\author{
Riska Agustin ${ }^{1 *}$, Rahmat Setiawan ${ }^{2}$ \\ ${ }^{1}$ Fakultas Ekonomi dan Bisnis Islam, Universitas Islam Negeri Sunan Ampel Surabaya \\ Email: riska.agustin@uinsby.ac.id \\ ${ }^{2}$ Fakultas Ekonomi dan Bisnis, Universitas Airlangga Surabaya \\ Email: rahmatsetiawan@feb.unair.ac.id \\ *penulis korespondensi
}

Masuk : 10-08-2021, revisi: 20-09-2021, diterima untuk diterbitkan : 21-09-2021

\begin{abstract}
ABSTRAK
Kinerja perusahaan tercermin dari meningkatnya nilai perusahaan karena perusahaan mampu mengelola sumber daya yang dimiliki. Hal ini membutuhkan keahlian, pengetahuan dan keefisiensian manajemen dalam mengelola sumber daya serta mengembangkan strategi yang tepat. Diversifikasi internasional merupakan strategi yang diterapkan perusahaan di era globalisasi ini untuk mengembangkan pangsa pasar internasional yang dapat meningkatkan kinerja perusahaan. Mengingat fakta bahwa sumber daya langka, kebutuhan untuk menjadi efisien merupakan fenomena penting dalam usaha peningkatan kinerja perusahaan. Penelitian ini bertujuan untuk mengetahui pengaruh efisiensi terhadap hubungan antara diversifikasi internasional terhadap kinerja perusahaan manufaktur. Dengan metode purposive sampling dan periode penelitian antara 2013-2017, kami mendapatkan data 69 perusahaan manufaktur dengan jumlah observasi sebanyak 223. Terdapat dua langkah teknik analisis yang digunakan yaitu dengan metode Data Envelopment Analysis (DEA) dan analisis regresi linier berganda. Kami menemukan bahwa diversifikasi internasional mempunyai pengaruh positif yang signifikan terhadap kinerja perusahaan manufaktur di Indonesia. Efisiensi memoderasi pengaruh positif diversifikasi internasional terhadap kinerja perusahaan.
\end{abstract}

Kata Kunci: DEA, diversifikasi internasional, efisiensi, manufaktur, kinerja perusahaan.

\begin{abstract}
The firm's performance is reflected in the increasing value of the company because the company is able to manage its resources. This requires management expertise, knowledge and management efficiency in managing resources and developing appropriate strategies. International diversification is a strategy implemented by companies in this era of globalization to develop international market share that can improve firm's performance. Given the fact that resources are scarce, the need to be efficient is an important phenomenon in an effort to improve firm performance. The purpose of this study was to determine the effect of efficiency on the relationship between international diversification on the performance of manufacturing firms. Using the purposive sampling method and the research period between 2013-2017, we obtained data from 69 manufacturing firms with a total of 223 observations. There are two steps of the analytical technique used, namely the Data Envelopment Analysis (DEA) and multiple linear regression method. We find that international diversification has a significant positive effect on the performance of manufacturing firms in Indonesia. Efficiency moderates the positive effect of international diversification on a firm's performance.
\end{abstract}

Keywords: DEA, international diversification, efficiency, manufacturing, firm's performance.

\section{PENDAhUluan}

Kinerja perusahaan dipandang sebagai alat ukur kesuksesan manajer dalam menjalankan dan mengelola sumber daya yang di miliki perusahaan agar dapat meningkatkan nilai perusahaan. Informasi dan data kinerja perusahaan tersebut dapat menjadi tolak ukur bagi kreditur, pemegang saham, pemerintah atau konsumen dalam melihat prospek masa depan perusahaan tersebut. Penilaian kinerja perusahaan dilakukan berdasarkan data keuangan melalui proses yang disebut dengan analisi keuangan yang bisa diukur melalui informasi akuntansi perusahaan ((Mukhopadhyay \& Chakraborty, 2017). Menurut (Chen \& Yu, 2012) diversifikasi merupakan 
strategi yang baik untuk meningkatkan kinerja perusahaan dalam jangka pendek yang berpotensi membantu usaha memperoleh akses terhadap keterampilan, sumber daya, aset, atau kompetensi yang tidak dapat dilakukan oleh perusahaan lain yang tidak melakukan diversifikasi di pasar yang kompetitif.

Menurut penelitian (Yang et al., 2017), diversifikasi merupakan strategi perluasan bidang usaha terhadap kekuatan pasar, industri dan segmen serta sektor yang sebagian besar disebabkan karena adanya persaingan dalam lingkungan bisnis yang semakin ketat. Jenis strategi diversifikasi dibedakan menjadi dua yaitu diversifikasi industri dan diversifikasi internasional (Jafarinejad et al., 2018) yang sama-sama memainkan peran penting dalam keputusan strategi yang akan dilakukan oleh perusahaan. Salah satu jenis strategi diversifikasi yang beberapa tahun terakhir ini bisa membuat perusahaan semakin berkembang ke pangsa pasar internasional sehingga dapat meningkatkan kinerja perushaaan adalah diversifikasi internasional (BenitoOsorio et al., 2016). Perusahaan yang melakukan diversifikasi internasional memiliki manfaat berupa keunggulan kompetitif pada pasar global dan peningkatan kinerja suatu organisasi (Altaf \& Shah, 2015). Menurut penelitian dari (Hsu et al., 2013), ekspansi internasional memberikan peluang kepada perusahaan untuk mengalami pertumbuhan dan kemudahan dalam mendapatkan akses pengetahuan di negara asing.

Peningkatan kinerja perusahaan yang disebabkan oleh diversifikasi internasional telah banyak diteliti. Dalam penelitian (Gao \& Chou, 2015), diversifikasi internasional bisa memberikan potensi keuntungan untuk meningkatan produktivitas $\mathrm{R} \& \mathrm{D}$, mampu mencapai skala ekonomi dalam kegiatan inovasi dan mempunyai akses yang lebih besar terhadap sumber daya manusia dan pengetahuan saham secara internasional sehingga dapat meingkatkan kinerja perusahaan. (Gyan et al., 2017) dalam penelitiannya menemukan bahwa diversifikasi internasional yang dilakukan perusahaan tidak berdampak terhadap kinerja perusahaan. Penelitian dari (GarridoPrada et al., 2019) menunjukkan bahwa hubungan antara diversifikasi internasional dan kinerja perusahaan tidak linier, akan tetapi membentuk U-Shape. Sedangkan menurut (Calabrese \& Manello, 2018), diversifkasi internasional mempunyai pengaruuh negatif terhadap kinerja perusahaan. Ketidakkonsistenan hasil penelitian tersebut memotivasi peneliti untuk mencoba memasukkan variabel moderasi dengan tujuan untuk mengetahui dampaknya terhadap hubungan diversifikasi internasional dan kinerja perusahan. Beberapa peneliti telah mencoba memasukkan variabel moderasi seperti struktur kepemilikan, efek lingkungan ekonomi, alat tata kelola perusahaan, efek teknologi (Gyan et al., 2017).

Dalam penelitian ini, peneliti akan memasukkan variabel moderasi efisiensi untuk mengetahui dampak variabel tersebut pada hubungan antara diversifikasi internasional dengan kinerja perusahaan manufaktur. Dalam meningkatkan kinerja perusahaan, efisiensi menjadi fenomena penting karena dengan adanya efisiensi, perusahaan mampu menggunakan sumber daya nya lebih tepat. Sesuai dengan hasil penelitian (Symeou \& Kretschmer, 2012), peningkatan kinerja pada perusahaan yang melakukan diversifikasi internasional dapat dicapai oleh mekanisme organisasi yang meningkatkan efisiensi. Efisiensi yang dilakukan manajemen perusahaan dalam mengalokasikan sumber daya perusahaan secara tepat merupakan bagian faktor kunci keberhasilan diversifikasi (Bettis \& Prahalad, 1995). Penggunaan variabel moderasi efisiensi perusahaan pada penelitian ini dilakukan dengan metode Data Envelopment Analysis (DEA) dengan bantuan software DEAP 21. Sehingga tujuan pada penelitian ini adalah untuk mengetahui pengaruh strategi diversifikasi internasional terhadap kinerja perusahaan manufaktur di Indonesia dan untuk mengetahui apakah efisiensi memoderasi hubungan strategi diversifikasi internasional dengan kinerja perusahaan manufaktur di Indonesia. 
Dengan melakukan diversifikasi internasional, perusahaan bisa memperoleh keuntungan yang beragam dan kekuatan pasar yang lebih besar. Diversifikasi internasional adalah pengembangan bisnis perusahaan diluar wilayah geografisnya yang bisa diukur dengan besarnya nilai penjualan luar negeri terhadap total penjualan perusahaan (Mukhopadhyay \& Chakraborty, 2017). Efisiensi mengukur sebesarapa baik suatu perusahaan menggunakan input minimal untuk menghasilkan output maksimal sehingga dapat memaksimalkan nilai perusahaan (Gyan et al., 2017). Suatu perusahaan dikatakan telah efisien ketika dapat mengalokasikan jumlah input atau sumber daya yang sama dengan perusahaan lain tetapi jumlah output yang dihasilkan lebih besar. Dalam penelitian (Baik et al., 2013), Perubahan efisiensi mencerminkan keuntungan perusahaan saat ini dan masa depan secara langsung dan memberikan kekuatan informasi kepada perusahaan untuk meningkatkan laba di masa depan. (Greene \& Segal, 2004) dalam penelitiannya menyebutkan bahwa nilai perusahaan dan efisiensi dalam pemanfaatan sumber daya perusahaan memiliki hubungan positif yang kuat. Berdasarkan teori yang telah dijelaskan, penelitian ini akan membahas hubungan antara diversifikasi internasional terhadap kinerja perusahaan yang di moderasi oleh variabel efisiensi.

Menurut (Madura, 2015), diversifikasi internasional merupakan strategi yang dilakukan perusahaan di era globalisasi ini untuk meningkatkan pangsa pasar perusahaan dengan mencari peluang pasar baru di luar negara asal. Dengan melakukan diversifikasi internasional, perusahaan mempunyai tambahan pengetahuan dan informasi dari para mitra bisnisnya di luar negeri yang selanjurnya dapat digunakan untuk melakukan inovasi (Vithessonthi \& Racela, 2016). Diversifikasi internasional juga dapat memberi kemudahan dalam mempromosikan dan menjual produknya karena pandangan dan kepercayaan konsumen terhadap perusahaan akan semakin tinggi. Jika perusahaan bisa menjual produknya lebih banyak, maka perusahaan bisa memperoleh manfaat dari penghematan biaya bahan baku dan produksi per unitnya (Qian et al., 2010). Peningkatan penjualan yang diimbangi dengan pengurangan biaya produksi dan biaya transaksi ini dapat meningkatkan profitabilitas perusahaan sehingga kinerja perusahaan juga mengalami peningkatan. Sehingga:

H1 : Diversifikasi internasional berpengaruh positif terhadap kinerja perusahaan.

Diversifikasi internasional bisa dilakukan dengan kegiatan ekpor, mengakuisisi perusahaan asing dan mendirikan anak perusahaan di luar negeri sehinga bisa memperluas pangsa pasar dan bersaing dengan kompetitornya secara global (Madura, 2015). Pengalokasian sumber daya terutama pada keahlian dan kemampuan manajemen secara efisien yang dilakukan perusahaan manjadi poin penting dalam keberhasilan diversifikasi ini. Potensi profitabilitas perusahaan bergantung pada kontrol sumber daya yang di miliki perusahaan tersebut (Chatterjee \& Wernerfelt, 1991). Sumber daya perusahaan yang mampu di alokasikan secara efisien akan menurunkan biaya transaksi yang dikeluarkan perusahaan. Biaya yang dikeluarkan perusahaan yang melakukan diversifikasi internasional akan lebih tinggi karena struktur organisasi nya lebih kompleks dan harus menghubungkan antar negara untuk melakukan transaksi (Denis et al., 1999). Dengan adanya tambahan manfaat yang diperoleh dari efisiensi pada perusahaan yang melakukan diversifikasi internasional, maka diharapkan juga akan meningkatkan kinerja perusahaan. Sehingga:

H2 : Pengaruh positif diversifikasi internasional terhadap kinerja lebih kuat pada perusahaan yang efisien dibandingkan dengan perusahaan yang tidak efisien. 


\section{METODE PENELITIAN}

Metodologi yang digunakan untuk menjawab rumusan masalah diatas diadopsi melalui penelitian dari (Gyan et al., 2017) namun beberapa proksi pengukuran yang digunakan memiliki perbedaan.

\section{Data}

Periode penggunaan data yang digunakan dari tahun 2013 hingga 2017 bersumber dari laporan keuangan tahunan perusahaan manufaktur yang tercatat di Bursa Efek Indonesia (BEI). Data tersebut dapat diambil dari website www.idx.co.id. Sampel penelitian ini diperoleh dengan menggunakan metode purposive sampling yang merupakan cara mengambil sampel tertentu dengan menggunakan batasan tertentu dalam menentukan sampel (Surjadi, 2019). Batasan tersebut adalah hanya perusahaan manufaktur yang mempublikasikan laporan keuangan tahunan secara konsisten dan memiliki data yang lengkap selama periode penelitian yang akan dijadikan sampel.

\section{Teknik Analisis Data}

Mengacu pada metodologi yang diusulkan oleh (Gyan et al., 2017), untuk mengetahui hubungan antara diversifikasi dan kinerja perusahaan yang dimoderasi oleh efisiensi dilakukan dengan dua langkah teknik analisis. Teknik analisis pertama adalah metode Data Envelopment Analysis (DEA) dengan menggunakan software DEAP 21 untuk menilai efisiensi perusahaan manufaktur Indonesia. Langkah kedua teknik analisis yang digunakan adalah dengan regresi linier berganda menggunakan software SPSS untuk mengetahui pengaruh dari diversifikasi internasional dengan kinerja perusahaan yang dimoderasi oleh variabel efisiensi dan memasukkan variabel kontrol umur dan ukuran perusahaan.

Dalam menentukan kinerja perusahaan digunakan pengukuran Return on Asset (ROA) (Delbufalo et al., 2016). Diversifikasi internasional diukur dengan indeks Export Sales to Total Sales (ESTS) (Xiao et al., 2013). Variabel efisiensi diukur dengan Data Envelopment Analysis (DEA) untuk menilai perusahaan yang tidak efisien dan efisien. Mengikuti penelitian yang dilakukan oleh (Doaei \& Shavazipour, 2013) dan (Gyan et al., 2017)), digunakan beberapa variabel output dan input untuk mengukur efisiensi karena pengaruh signifikan variabel-variabel tersebut terhadap kinerja perusahaan manufaktur. Variabel input yang digunakan adalah Ukuran perusahaan, leverage, dan capital investment. Variabel output yang digunakan adalah Return on Equity (ROE), Net Profit Margin (NPM) dan Market to Book Ratio (MBR). Tabel 1 berisi definisi variabel-variabel beserta pengukurannya yang digunakan dalam penelitian ini.

Tabel 1. Definisi variabel dan pengukurannya

\begin{tabular}{c|l|l}
\hline & \multicolumn{1}{|c}{ Variabel } & \multicolumn{1}{c}{ Rumus } \\
\hline Kinerja Perusahaan & Return on Asset $($ ROA $)$ & net income per total asset \\
\hline Diverifikasi & Diversifikasi internasional & Export sales to total sales \\
\hline \multirow{5}{*}{ Kontrol } & Ukuran perusahaan & Ln (total aset) \\
\cline { 2 - 3 } & Umur perusahaan & $\begin{array}{l}\text { Tahun berdirinya perusahaan hingga } \\
\text { periode penelitian }\end{array}$ \\
\hline \multirow{5}{*}{ Efisiensi } & Return on Equity $($ ROE $)$ & net income per total equity \\
\cline { 2 - 3 } & Net Profit Margin $(N P M)$ & $\begin{array}{l}\text { Met income per total sales } \\
\text { per share }\end{array}$ \\
\cline { 2 - 3 } & Market to Book Ratio $(M B R)$ & Ln (total aset) \\
\cline { 2 - 3 } & Ukuran perusahaan & Total debt per total asset \\
\cline { 2 - 3 } & Leverage & Capital expenditure per total asset \\
\cline { 2 - 3 } & Capital Investment & \\
\hline
\end{tabular}


Konsep Efisiensi menurut (Coelli, 1996), didefinisikan sebagai rasio antara output yang dapat dihasilkan perusahaan dan input yang dimiliki perusahaan. Ketika satu unit input yang dimiliki perusahaan dapat menghasilkan lebih banyak output maka secara relatif akan menghasilkan nilai efisiensi yang lebih tinggi. Sebuah perusahaan dikatakan telah mencapai efisiensi optimal ketika tingkat output yang dihasilkan dari satu unit input telah mencapai jumlah yang maksimal yang bisa dihasilkan. Untuk mengukur tingkat efisiensi digunakan pendekatan non parametrik, dalam penelitian ini digunakan metode Data Envelopment Analysis (DEA). DEA adalah metode yang diturunkan dari program matematika yang digunakan untuk mengukur efisiensi sebuah perusahaan. Nilai efisiensi berasal dari unit-unit yang membuat keputusan sebuah perusahaan dalam mengoperasikan sumber daya (input) yang dimiliki untuk menghasilkan output (Charles \& Cornillier, 2017)

DEA merupakan metode terapan program linier dalam menilai efisiensi relatif dari setiap unit produksi sebuah perusahaan yang dibandingkan dengan unit produksi lain yang memiliki tujuan yang sama dengan hasil skor jika efisien bernilai 1 dan jika tidak efisien bernilai selain 1 (Fazlollahi \& Franke, 2018). Dalam DEA, unit produksi disebut Decision Making Unit (DMU) yang didefinisikan sebagai unit yang diuji, dapat berupa perusahaan maupun instansi yang ingin diteliti (Zhu et al., 2018). Sesuai dengan metodologi dari (Gyan et al., 2017), persamaan efisiensi didefinisikan sebagai berikut:

$$
\max _{v, u} \theta=\frac{\sum_{r=1}^{s} u_{1} y_{1 j}+u_{2} y_{2 j}+\cdots u_{s} y_{s j}}{\sum_{i=1}^{m} v_{1} x_{1 j}+v_{2} x_{2 j}+\cdots v_{m} x_{m j}}
$$

Dengan:

$$
\begin{gathered}
\frac{\sum_{r=1}^{s} u_{r} y_{r j}}{\sum_{i=1}^{m} v_{i} x_{i j}} \leq 1, j=1, \ldots, d \\
u_{1}, u_{2}, \ldots, u_{s} \geq 0 \\
v_{1}, v_{2}, \ldots, v_{m} \geq 0
\end{gathered}
$$

J adalah DMU yang diteliti, s adalah output DMU j yang diteliti, $m$ adalah input DMU $\mathrm{j}$ yang diteliti, $\mathrm{u}$ adalah bobot output DMU $\mathrm{j}$ yang diteliti, y adalah jumlah output DMU $\mathrm{j}$ yang diteliti, $\mathrm{v}$ adalah bobot input DMU $\mathrm{j}$ yang diteliti, dan $\mathrm{x}$ adalah jumlah input DMU $\mathrm{j}$ yang diteliti. Persamaan (1) menunjukkan bahwa d merupakan jumlah DMU pada sampel, j menunjukkan tipe DMU yang dijadikan sampel. Persamaan pertama merepresentasika bahwa adanya rasio untuk nilai DMU lainnya dalam sampel kurang dari atau sama dengan 1, sedangkan persamaan kedua dan ketiga merepresentasikan bahwa bobot lebih besar dari nol atau bernilai positif.

Teknik analisis selanjutnya adalah regresi linier berganda dengan menguji masing-masing variabel dengan metode uji asumsi klasik, uji t. dan melakukan analisis regresi linier berganda untuk masing-masing model penelitian yang telah disusun sebagai berikut:

Model 1: Untuk mengetahui dampak diversifikasi internasional dengan variabel kontrol yaitu age dan firm size terhadap kinerja perusahaan, maka dibentuk model persamaan regresi sebagai berikut:

$$
\text { KINERJA }_{i, t}=\alpha+\beta_{1} \text { DIVINTER }+\beta_{2} U M U R+\beta_{3} U K U R A N+\varepsilon_{i, t}
$$

Model 2 : Untuk mengetahui dampak diversifikasi internasional dengan variabel kontrol yaitu age dan firm size terhadap kinerja perusahaan yang dimoderasi oleh variabel efisiensi, maka dibentuk model persamaan regresi sebagai berikut: 


$$
\begin{gathered}
\text { KINERJA }_{i, t}=\alpha+\beta_{1} \text { DIVINTER }+\beta_{2} \text { EFISIEN }+\beta_{3} \text { DIVINTER }^{*} \text { EFISIEN } \\
+\beta_{4} U M U R+\beta_{5} U K U R A N+\varepsilon_{i, t}
\end{gathered}
$$

\section{HASIL DAN PEMBAHASAN}

Pada penelitian ini didapatkan 69 data perusahaan manufaktur di Indonesia dengan jumlah observasi sebanyak 223. Data sampel tersebut akan dianalisis dengan menggunakan 2 langkah teknik analisis yaitu DEA dan regresi linier berganda.

\section{Hasil analisis efisiensi perusahaan dengan DEA}

Dalam menentukan tingkat efisiensi perusahaan manufaktur digunakan teknik analisis DEA dengan menggunakan software DEAP 21. Berdasarkan perhitungan yang dihasilkan oleh software, skor efisiensi bernilai antara 0-1. Skor efisiensi kurang dari 1 menyatakan bahwa perusahaan tersebut relatif tidak efisien dan skor sama dengan 1 menyatakan bahwa perusahaan tersebut relatif efisien. Jumlah tingkat efisiensi perusahaan manufaktur di Indonesia pada periode penelitian antara 2013 hingga 2017 disajikan pada Tabel 2 berikut ini:

Tabel 2. Jumlah tingkat efisiensi perusahaan

\begin{tabular}{lcccccc}
\hline & \multicolumn{7}{c}{ Tahun } \\
\cline { 2 - 7 } & 2013 & 2014 & 2015 & 2016 & 2017 & Total \\
\hline Efisien & 6 & 5 & 6 & 9 & 6 & 32 \\
\hline Tidak efisien & 39 & 44 & 36 & 34 & 38 & 191 \\
\hline Total & 45 & 49 & 42 & 43 & 44 & 223 \\
\hline
\end{tabular}

\section{Hasil analisis regresi linier berganda}

Hasil pengujian masing-masing variabel dengan menggunakan analisis regresi berganda telah memenuhi syarat uji asumsi klasik yang ditunjukkan dari hasil output SPSS 21. Pengujian selanjutnya adalah untuk melihat pengaruh koefisien variabel independen secara parsial terhadap dependen terikat dengan melihat nilai korelasi antar variabel. Hasil output SPSS 21 mengenai matriks korelasi antar variabel disajikan dalam Tabel 3 berikut ini:

\begin{tabular}{|c|c|c|c|c|c|c|}
\hline & KINERJA & DIVINTER & UMUR & UKURAN & EFISIEN & INTEREFI \\
\hline KINERJA & 1 & & & & & \\
\hline DIVINTER & $0,113^{*}$ & 1 & & & & \\
\hline UMUR & $0,342^{* * *}$ & $-0,137 * *$ & 1 & & & \\
\hline UKURAN & $0,244 * *$ & 0,031 & $0,295 * *$ & 1 & & \\
\hline EFISIEN & $0,319 * *$ & $-0,119$ & 0,068 & $-0,269 * *$ & 1 & \\
\hline INTEREFI & $0,305^{* *}$ & $0,223 * *$ & 0,063 & 0,016 & $0,351 * *$ & 1 \\
\hline
\end{tabular}

Tabel 3. Matriks Korelasi

$*, * *$ Correlation is significant at the $1 \%, 5 \%$

Berdasarkan tabel 3 diatas, variabel independen atau diversifikasi internasional (DIVINTER) mempunyai korelasi positif signifikan terhadap variabel dependen atau kinerja perusahaan (KINERJA). Untuk variabel kontrol yaitu variabel umur perusahaan (UMUR) dan variabel ukuran perusahaan (UKURAN) juga mempunya korelasi positif signifikan terhadap variabel kinerja perusahaan (KINERJA). Variabel moderasi yaitu efisiensi juga mempunyai korelasi positif signifikan terhadap variabel kinerja perusahaan. Sehingga dapat disimpulkan bahwa korelasi antara variabel independen, kontrol dan moderasi adalah positif signifikan terhadap variabel dependen. 
Pengujian selanjutnya adalah analisis regresi linier berganda untuk masing-masing model penelitian dengan menggunakan SPSS 21. Hasil output analisis regresi linier berganda tersebut disajikan dalam Tabel 4 berikut ini:

Tabel 4. Hasil analisis regresi linier berganda

\begin{tabular}{lll}
\hline Variabel & Model 1 & Model 2 \\
\hline Constant & $-0,077^{*}$ & $-0,141^{* *}$ \\
\hline DIVINTER & $(0,040)$ & $(0,000)$ \\
\hline UMUR & $0,055^{*}$ & $0,055^{*}$ \\
\hline UKURAN & $(0,016)$ & $(0,012)$ \\
\hline EFISIEN & $0,001^{* *}$ & $0,001^{* *}$ \\
\hline INTEREFI & $(0,000)$ & $(0,000)$ \\
\hline $0,006^{*}$ & $0,010^{* *}$ \\
\hline R-Square & $(0,027)$ & $(0,000)$ \\
\hline Signiffcance $* \%$ & $0,0763^{* *}$ \\
\hline
\end{tabular}

Significance $* 5 \%, * * 1 \%$

\section{Pengaruh Diversifikasi Internasioanal terhadap Kinerja Perusahaan.}

Pada Tabel 4 model 1, diketahui bahwa diversifikasi internasional (DIVINTER) mempunyai pengaruh positif signifikan terhadap kinerja perusahaan (KINERJA). Nilai signifikansi variabel DIVINTER adalah 0,016 yang berarti $\leq 0,05$ sehingga dapat disimpulkan bahwa hipotesis penelitian $\mathrm{H}_{1}$ diterima, yang berarti semakin tinggi diversifikasi internasional yang dilakukan perusahaan, maka semakin tinggi kinerja perusahaan tersebut. Dengan diversifikasi internasional, perusahaan mempunyai tambahan pengetahuan dan informasi dari mitra bisnisnya untuk melakukan inovasi (Vithessonthi \& Racela, 2016). Pengetahuan tersebut berguna untuk mengembangkan kemampuan suatu perusahaan agar dalam proses pengambilan keputusan dapat dilakukan secara tepat.

Dengan berkomunikasi dengan berbagai mitra bisnis internasional, supplier dan konsumen, perusahaan akan memiliki kesempatan dan kemampuan yang lebih besar dalam mengakses berbagai macam sumber daya global seperti teknologi informasi yang tinggi (Gao \& Chou, 2015). Kemudahan akses dan inovasi yang dilakukan perusahaan yang berekspansi ke luar negeri diharapkan dapat memberikan peluang pangsa pasar yang lebih besar dan mempersempit ruang gerak para pesaingnya. Peluang pangsa pasar yang lebih besar pada perusahaan berpotensi meningkatkan penjualan perusahaan. Semakin banyak produk yang terjual maka perusahaan dapat memperoleh penghematan biaya yang diperoleh dari biaya per unit produk yang lebih rendah. Peningkatan penjualan yang diimbangi dengan pengurangan biaya yang dikeluarkan perusahaan akan meningkatkan profitabilitas perusahaan.

Hasil penelitian ini sejalan dengan hasil penelitian yang dilakukan oleh (Altaf \& Shah, 2015), sebuah perusahaan yang melakukan diversifikasi internasional di hadapkan kepada berbagai 
tantangan akan keragaman pasar global, hal ini dapat memberikan kesempatan untuk meningkatan pengetahuan dan kemampuan baru yang bermanfaat bagi seluruh organisasi perusahaan. Manfaat ini mendorong perusahaan untuk mendapatkan keunggulan kompetitif di pasar global sehingga dapat meningkatkan kinerja perusahaan. Menurut (Calabrese \& Manello, 2018), volume ekspor yang lebih besar pada perusahaan yang melakukan diversifikasi internasional memungkinkan perusahaan untuk mencapai skala ekonomi yang lebih luas sehingga produktivitas tenaga kerja, efisiensi manajemen, profitabilitas dan kinerja perusahaan mengalami peningkatan.

\section{Efek moderasi efisiensi pada pengaruh diversifikasi internasional dan kinerja perusahaan}

Pada Tabel 4 model 2, hasil interaksi antara variabel diversifikasi industri dan efisiensi (INTEREFI) bertanda positif signikan menunjukkan bahwa efisiensi memperkuat pengaruh positif diversifikasi internasional terhadap kinerja perusahaan. Nilai signifikansi variabel INTEREFI adalah 0,039 yang berarti $\leq 0,05$ sehingga dapat disimpulkan bahwa hipotesis penelian $\mathrm{H}_{2}$ diterima, yang berarti bahwa efisiensi yang dilakukan perusahaan memoderasi pengaruh positif diversifikasi internasional terhadap kinerja perusahaan. Diversifikasi internasional dalam penelitian ini dihitung berdasarkan rasio penjualan luar negeri atau ekspor. Perusahaan yang melakukan ekspor akan mempunyai akses yang lebih baik pada lingkungan yang baru, teknologi asing yang lebih maju dan subsidi pada modal yang digunakan seperti biaya mesin dan peralatan yang lebih rendah (Aw \& Hwang, 1995). Oleh karena itu, kegiatan ekspor dapat membuat ruang lingkup perusahaan menjadi lebih besar dan mampu mencapai skala ekonominya sehingga dapat meningkatkan produktivitas tenaga kerja, efisiensi manajemen dan profitabilitas (Calabrese \& Manello, 2018).

Peningkatkan produktivitas dapat mendorong penggunaan input perusahaan menjadi lebih efisien (Aw \& Hwang, 1995). Hal ini disebabkan karena pasar internasional lebih kompetitif dan persaingannya semakin ketat sehingga membuat perusahaan-perusahaan tersebut menempatkan standar efisiensi yang lebih baik pada proses produksinya. Standar efisiensi yang ditetapkan pada perusahaan dapat meminimalkan ketidakefisienan pada proses produksi dalam hal waktu, tenaga kerja maupun anggaran yang dikeluarkan perusahaan. Sehingga semakin baik efisiensi yang dilakukan manajemen perusahaan dalam melakukan ekspor, maka profitabilitas yang diperoleh perusahaan juga mengalami peningkatan.

Hasil penelitian ini sejalan dengan hasil penelitian yang dilakukan oleh (Wagner, 2004), bahwa efisiensi dalam hal biaya merupakan mediator penting bagi perusahaan yang melakukan diversifikasi internasional terhadap tingkat kinerja perusahaan. Perusahaan yang melakukan diversifikasi internasional akan mengalami peningkatan kompleksitas perusahaan secara eksternal maupun internal. Oleh karena itu diperlukan efisiensi biaya potensial agar faktor-faktor kompleksitas tersebut berhasil dikelola dengan baik sehingga manfaat dari adanya diversifikasi internasional yang dilakukan perusahaan akan lebih meningkatkan kinerja perusahaan tersebut.

\section{KESIMPULAN DAN SARAN}

Setelah dilakukan dua langkah analisis dengan metode DEA yang bertujuan untuk mengukur nilai efisiensi perusahaan dan analisis regresi linier berganda yang bertujuan untuk mengetahui pengaruh antar variabel, maka didapatkan hasil penelitian yaitu diversifikasi internasional mempunyai pengaruh positif signifikan terhadap kinerja perusahaan. Ketika tingkat diversifikasi internasional semakin tinggi, maka semakin tinggi pula kinerja perusahaan. Variabel moderasi efisiensi menunjukkan hasil bahwa efisiensi memoderasi pengaruh positif diversifikasi internasioanal terhadap kinerja perusahaan. Dengan kata lain, efisiensi memperkuat pengaruh 
positif diversifikasi internasional yang dilakukan perusahaan terhadap kinerja perusahaan tersebut. Dalam penelitian ini, kinerja perusahaan hanya diukur menggunakan Return on Assets (ROA) yang menjelaskan kemampuan aktiva yang dimiliki perusahaan mampu menghasilkan laba setelah pajak yang digunakan dalam aktivitas operasional perusahaan. Saran bagi penelitian selanjutnya adalah menggunakan pengukuran laporan keuangan yang lain dalam mengukur kinerja perusahaan.

\section{Ucapan Terima Kasih}

Alhamdulillah syukur kepada Allah SWT, karena atas rahmat dan ridha-Nya peneliti dapat menyempurnakan tulisan ini. Oleh karena itu penulis ingin menyampaikan terima kasih yang sebesar-besarnya kepada orang-orang yang telah mendukung dalam penyelesaian tulisan ini. Kepada Bapak Dr. Rahmat Setiawan, SE., MM., CFP., AEPP yang merupakan dosen pembimbing sekaligus kaprodi MSM UNAIR. Kepada kedua orang tua, suami dan anak serta teman-teman semua yang selalu mendukung dan membantu proses penyelesaian jurnal ini juga saya ucapkan terima kasih.

\section{REFERENSI}

Altaf, N., \& Shah, F. A. (2015). Internationalization and firm performance of Indian firms: Does product diversity matter? Pacific Science Review B: Humanities and Social Sciences, 1(2), 76-84. https://doi.org/10.1016/j.psrb.2016.05.002

Aw, B. Y., \& Hwang, A. R. (1995). Productivity and the export market: A firm-level analysis. Journal of Development Economics, 47(2), 313-332. https://doi.org/10.1016/03043878(94)00062-H

Baik, B., Chae, J., Choi, S., \& Farber, D. B. (2013). Changes in operational efficiency and firm performance: A frontier analysis approach. Contemporary Accounting Research, 30(3), 996-1026. https://doi.org/10.1111/j.1911-3846.2012.01179.x

Benito-Osorio, D., Colino, A., Guerras-Martín, L. Á., \& Zúñiga-Vicente, J. Á. (2016). The international diversification-performance link in Spain: Does firm size really matter? International Business Review, 25(2), 548-558. https://doi.org/10.1016/j.ibusrev.2015.09.004

Bettis, R. A., \& Prahalad, C. K. (1995). The dominant logic: Retrospective and extension. Strategic Management Journal, 16(1), 5-14. https://doi.org/10.1002/smj.4250160104

Calabrese, G. G., \& Manello, A. (2018). Firm internationalization and performance: Evidence for designing policies. Journal of Policy Modeling, 40(6), 1221-1242. https://doi.org/10.1016/j.jpolmod.2018.01.008

Charles, V., \& Cornillier, F. (2017). Value of the stochastic efficiency in data envelopment analysis. Expert Systems with Applications, 81, 349-357. https://doi.org/10.1016/j.eswa.2017.03.061

Chatterjee, S., \& Wernerfelt, B. (1991). The link between resources and type of diversification: Theory and evidence. Strategic Management Journal, 12(1), 33-48. https://doi.org/10.1002/smj.4250120104

Chen, C. J., \& Yu, C. M. J. (2012). Managerial ownership, diversification, and firm performance: Evidence from an emerging market. International Business Review, 21(3), 518-534. https://doi.org/10.1016/j.ibusrev.2011.06.002

Coelli, T. . (1996). A Guide to DEAP Version 2.1: Data Envelopment Analysis (Computer) Program.pdf. CEPA Working Paper No.8. Department of Econometrics.

Delbufalo, E., Poggesi, S., \& Borra, S. (2016). Diversification, family involvement and firm performance: Empirical evidence from Italian manufacturing firms. Journal of Management Development, 35(5), 663-680. https://doi.org/10.1108/JMD-09-2015-0129 
Denis, D. J., Denis, D. K., \& Yost, K. (1999). Global Diversification, Industrial Diversification, and Firm Value.

Doaei, M., \& Shavazipour, B. (2013). Corporate diversification's effects on Efficiency and productivity: case study of Manufacturing firms listed in Bursa Malaysia. International Journal of Business and Development Studies, 5(August), 77-96.

Fazlollahi, A., \& Franke, U. (2018). Measuring the impact of enterprise integration on firm performance using data envelopment analysis. International Journal of Production Economics, 200, 119-129. https://doi.org/10.1016/j.ijpe.2018.02.011

Gao, W., \& Chou, J. (2015). Innovation efficiency, global diversification, and firm value. Journal of Corporate Finance, 30, 278-298. https://doi.org/10.1016/j.jcorpfin.2014.12.009

Garrido-Prada, P., Delgado-Rodriguez, M. J., \& Romero-Jordán, D. (2019). Effect of product and geographic diversification on company performance: Evidence during an economic crisis. European Management Journal, 37(3), 269-286. https://doi.org/10.1016/j.emj.2018.06.004

Greene, W. H., \& Segal, D. (2004). Profitability and efficiency in the U.S. life insurance industry. Journal of Productivity Analysis, 21(3), 229-247. https://doi.org/10.1023/B:PROD.0000022092.70204.fa

Gyan, A. K., Brahmana, R., \& Bakri, A. K. (2017). Diversification strategy, efficiency, and firm performance: Insight from emerging market. Research in International Business and Finance, 42, 1103-1114. https://doi.org/10.1016/j.ribaf.2017.07.045

Hsu, W. T., Chen, H. L., \& Cheng, C. Y. (2013). Internationalization and firm performance of SMEs: The moderating effects of CEO attributes. Journal of World Business, 48(1), 1-12. https://doi.org/10.1016/j.jwb.2012.06.001

Jafarinejad, M., Ngo, T., \& Escobari, D. (2018). Disentangling the impacts of industrial and global diversification on firm risk. Global Finance Journal, 37(2017), 39-56. https://doi.org/10.1016/j.gfj.2018.04.006

Madura, J. (2015). International Financial Management.pdf(12th Editi). Cengage learning.

Mukhopadhyay, J., \& Chakraborty, I. (2017). Foreign institutional investment, business groups and firm performance: Evidence from India. Research in International Business and Finance, 39, 454-465. https://doi.org/10.1016/j.ribaf.2016.09.015

Qian, G., Khoury, T. A., Peng, M. W., \& Qian, Z. (2010). THE PERFORMANCE IMPLICATIONS OF INTRA- AND INTER-REGIONAL GEOGRAPHIC DIVERSIFICATION. Business, 31(9)(March), 1018-1030. https://doi.org/10.1002/smj

Surjadi, L. (2019). Faktor Yang Memengaruhi Nilai Perusahaan Manufaktur Yang Terdaftar Di Bei. Jurnal Muara Ilmu Ekonomi Dan Bisnis, 3(2), 331. https://doi.org/10.24912/jmieb.v3i2.5969

Symeou, P., \& Kretschmer, T. (2012). Diversification and firm performance in dynamic environments : the role of the firm? s dynamic capabilities and absorptive capacity . Diversification and firm performance in dynamic environments : the. Druid 2012, 0-26. http://druid8.sit.aau.dk/acc_papers/q35k9nvmh1aeqv0xspxrpd0ymu5d.pdf

Vithessonthi, C., \& Racela, O. C. (2016). Short- and long-run effects of internationalization and R\&D intensity on firm performance. Journal of Multinational Financial Management, 34, 28-45. https://doi.org/10.1016/j.mulfin.2015.12.001

Wagner, H. (2004). Internationalization speed and cost efficiency: Evidence from Germany. International Business Review, 13(4), 447-463. https://doi.org/10.1016/j.ibusrev.2004.05.001 
Xiao, S. S., Jeong, I., Moon, J. J., Chung, C. C., \& Chung, J. (2013). Internationalization and Performance of Firms in China: Moderating Effects of Governance Structure and the Degree of Centralized Control. Journal of International Management, 19(2), 118-137. https://doi.org/10.1016/j.intman.2012.12.003

Yang, Y., Cao, Y., \& Yang, L. T. (Grace). (2017). Product diversification and property performance in the urban lodging market: The relationship and its moderators. Tourism Management, 59, 363-375. https://doi.org/10.1016/j.tourman.2016.08.018

Zhu, Q., Wu, J., \& Song, M. (2018). Efficiency evaluation based on data envelopment analysis in the big data context. Computers and Operations Research, 98, 291-300. https://doi.org/10.1016/j.cor.2017.06.017 